\title{
FUNCTIONAL FEATURES OF HEMODYNAMIC CHANGES IN PRETERM KIDS IN RESIDUAL PERIOD OF DEVELOPMENT
}

\author{
*L.E.Vigovskaya, A.R. Gaynutdinov \\ Kazan State Medical Academy, Kazan, RF
}

\begin{abstract}
Results of dopplerographic studies have delineate the severity of cerebrovascular disorders in different categories of preterm infants. The most significant hemodynamic changes characteristic for extremely premature infants, regardless of severity of the condition at birth, which is manifested as a decrease in blood flow through the main vessels of the head and neck, especially pronounced disturbances in the venous system of the brain. Birth trauma is a trigger factor in the implementation of hemodynamic disorders of the brain in these patients.
\end{abstract}

Key words: preterm, gestational age, severity of condition upon birth, hemodynamic dysfunctions.

B asis for organic cerebral pathology in preterm kids is founded mainly due to impact of pathogen factors in perinatal period of development $[1,2,5]$. Preterm kids start their lives with significantly higher volume of blood than full-term ones. Activation of compensatory functions of non-mature brain promotes formation of fully developed cerebrovascular anastomoses, accelerated maturation of venous pathways of blood outflow, and high potential for collateral blood circulation $[4,6]$. In its turn, existence of differentiated principle of blood distribution explains varying frequency of damage of individual brain segments in preterm kids with antenatal hypoxia $[3,5,7]$. Compensatory redistribution of blood in brainstem and spinal cord with the formation of Cerebral Steal Syndrome (mixed blood circulation of areas fed by anterior, medial, and posterior cerebral arteries, periventricular white substance) occurs in unfavorable conditions. $[1,3,4,8]$.

Equally important role is played by birth trauma in this process. Vertebral arteries provide blood to brainstem structures and acute deficiency of blood circulation in vertebrobasilar basin causes compensatory release of blood from anterior parts of brain to posterior sections, which deteriorates ischemic process in higher located structures $[5,9,10]$.

Purpose of Study to observe specifics of hemodynamic changes in preterm kids with neurologic disorders in residual period of development.

Materials and Methods. Dopplerographic investigation of cerebral vessels was conducted in 171 patients. Age of patients ranged between 718 years.

Depending on the severity of condition upon *e-mail: larisa-vigovskaia@rambler.ru birth, examined children were divided into two groups: main group and control group. 69 patients born with signs of hypoxia of various degree were examined, $21(31.3 \%)$ of which were patients with first degree of prematurity (Subgroup 1), 22 (27.2\%) with second degree of prematurity (Subgroup 2), 16 (30.8\%) with third degree of prematurity (Subgroup 3), and 10 $(45.5 \%)$ with fourth degree of prematurity (Subgroup 4).

In control group condition of cerebral vessels was evaluated in 102 patients, 54 (51\%) of which were patients with first degree of prematurity (Subgroup 1), 31 (57\%) with second degree of prematurity (Subgroup 2), $12(52 \%)$ with third degree of prematurity (Subgroup 3), and 5 (55\%) with fourth degree of prematurity (Subgroup 4). All children were born with no signs of cerebral hypoxia.

Results related to hemodynamic changes in cerebral vessels in patients of main group are presented in Tables 1 and 2 .

Hemodynamic changes in extracranial level manifested with spasms of a.vertebralis in $13.44 \%$ of patients of Subgroup 1, $14.8 \%$ of patients in Subgroup 2, 7.7\% and 27.3\% in very preterm patients of Subgroups 3 and 4, respectively; however, bilateral hemodynamic changes within physiologic range (up to $25 \%$ ) was mostly seen in very preterm patients of Subgroup $4(18.2 \%) \quad(\mathrm{p}<0.05)$ (Table 1). These dysfunctions in mentioned category of patients coincided with dystonic reactions in carotid basin, which presented with low arteriole tonus, venous dyscirculation in ophthalmic veins, and pronounced difficulty in venous outflow (Table 2). 


\section{Comparative Characteristics of Hemodynamic Changes on Extracranial Level in Preterm Patients of Main Group}

\begin{tabular}{|l|l|l|l|l|}
\hline \multirow{2}{*}{ Type of Change (\%) } & Degree of prematurity & \multicolumn{3}{l|}{} \\
\cline { 2 - 5 } & 1 & 2 & 3 & 4 \\
\hline Spasm of vertebral artery (total) & 13.44 & 14.8 & 7.7 & $27.3^{*}$ \\
\hline - right & 4.48 & 6.17 & 3.85 & 9.1 \\
\hline - left & 1.49 & 2.47 & 1.92 & - \\
\hline - bilateral & 7.47 & 6.17 & 1.92 & $18.2^{*}$ \\
\hline Deceleration of bloodstream in vertebral arteries up to 25\% & 16.42 & 11.11 & 19.24 & 18.2 \\
\hline - right & 5.97 & 4.94 & 5.77 & - \\
\hline - left & 4.48 & 2.47 & $9.62^{*}$ & - \\
\hline - Bilateral & 5.97 & 2.47 & 3.85 & $18.2^{*}$ \\
\hline
\end{tabular}

* - statistically significant difference $\mathrm{p}<0.05$

Hence, findings of Dopplerographic investigation allow making a conclusion that no significant hemodynamic changes are present in cerebrovascular system in patients of main group with first and second degree of prematurity. Simultaneously, signs of dystonia in carotid basin are seen in patients with third and fourth degree of prematurity, while staying within norm range in total. In very preterm patients with fourth degree of prematurity, prevailing damage is seen in vertebrobasilar basin, which presents with bilateral spasm of veretebral arteries.
Analysis of hemodynamic changes in control group is presented in Tables 3 and 4. Similar to main group, extracranial hemodynamic changes were observed more frequently in Subgroups 3 and 4 in form of bilateral spasm of vertebral arteries (13\% and $11 \%$, respectively) (Table 3 ). $11 \%$ of patients in Subgroup 4 had combination of the above-mentioned damage with bilateral delay in blood circulation of vertebral arteries within physiological norm range $(\mathrm{p}<0.05)$. The same patients had significantly higher incidence of dystonic reactions in carotid basin of various etiology (Table 4).

Table 2

\section{Comparative Characteristics of Intracranial Hemodynamic Changes in Preterm Patients of Main Group}

\begin{tabular}{|l|l|l|l|l|}
\hline Type of Change (\%) & Degree of prematurity & 3 & 4 \\
\cline { 2 - 5 } & 1 & 2 & 3 & $6.17^{*}$ \\
\hline Low tonus of arterioles & 2.99 & 1.92 & 4.55 \\
\hline Disruption of venous blood circulation in ophthalmic veins & 2.99 & 1.92 & $6.17^{*}$ & 4.55 \\
\hline $\begin{array}{l}\text { Steady impediment of blood circulation } \\
\text { in intracranial segment of vertebral artery }\end{array}$ & 2.99 & - & - \\
\hline Mild venous dystonia & 9.6 & 8.64 & 13.7 & $17.9^{*}$ \\
\hline Pronounced difficulty of venous outflow & 1.5 & 2.47 & 1.92 & $4.55^{*}$ \\
\hline $\begin{array}{l}\text { Deceleration of bloodstream in main } \\
\text { cerebral vessels up to 25\% }\end{array}$ & 7.45 & 2.47 & 3.85 & $13.7^{*}$ \\
\hline
\end{tabular}

* - statistically significant difference $p<0.05$

Table 3

Comparative Characteristics of Extracranial Hemodynamic Changes in Preterm Patients of Control Group

\begin{tabular}{|l|l|l|l|l|}
\hline Type of Change (\%) & Degree of prematurity & \multicolumn{4}{l|}{} \\
\cline { 2 - 5 } & 1 & 2 & 3 & 4.2 \\
\hline Spasm of vertebral artery (total) & 8.6 & 11.2 & 17.3 & $22^{*}$ \\
\hline - right & 3.8 & 1.9 & 4.3 & $11^{*}$ \\
\hline - left & 1 & 1.9 & - & - \\
\hline - bilateral & 3.8 & 7.4 & 4,3 & $11^{*}$ \\
\hline Deceleration of bloodstream in vertebral arteries up to 25\% & 7.7 & 9.4 & 4.3 & $11^{*}$ \\
\hline
\end{tabular}

* - statistically significant difference, $p<0.05$ 


\section{Comparative Characteristics of Intracranial Hemodynamic Changes in Preterm Patients of Control Group}

\begin{tabular}{|l|l|l|l|l|}
\hline Type of Change (\%) & Degree of prematurity & 3 & 4 \\
\cline { 2 - 5 } & 1 & 2 & - & 1 \\
\hline Low tonus of arterioles & 4.8 & 5.6 & - & $11^{*}$ \\
\hline Disruption of venous blood circulation in ophthalmic veins & 2.9 & 3.7 & 4.3 & $11^{*}$ \\
\hline $\begin{array}{l}\text { Steady impediment of blood circulation } \\
\text { in intracranial segment of vertebral artery }\end{array}$ & 2.9 & 1.9 & - \\
\hline Mild venous dystonia & & 5.8 & 3.7 & 4.3 \\
\hline Pronounced difficulty of venous outflow & - & 1.9 & - & - \\
\hline Deceleration of bloodstream in main cerebral vessels up to 25\% & 2 & 5.7 & 8.6 & - \\
\hline
\end{tabular}

* - statistically significant difference $\mathrm{p}<0.05$

Thus, performed dopplerographic investigations reveal that, upon presence of similar qualitative values for hemodynamic changes in preterm patients in main and control groups, the key role is attributed to the gestational age at the time of birth rather than severity of newborn's general condition.

\section{Conclusions:}

1. Analysis of cerebrovascular system's status in patients born prematurely has shown that regardless of severity of condition upon birth,

\section{REFERENCES}

1. Барашнев Ю.А. Клинико-морфологическая характеристика и методы церебральных расстройств при гипоксически-ишемических энцефалопатиях / Ю.А. Барашнев // Акушерство и гинекология - 2000. - №5. C. $39-42$

2. Белоусова Е.Д. Роль перивентрикулярной лейкомаляции в развитии детского церебрального паралича /Е.Д. Белоусова, М.Ю. Никанорова, Е.С. Кешишян [и др.] // Российский вестник перинатологии и педиатрии. - 2001. - №5. - С.26-32

3. Долгих Г.Б. Клинико-доплерографические особенности церебральных венозных дистоний у детей /Г.Б. Долгих // Методическое пособие для врачей.- Казань, 2005. - $126 \mathrm{c}$.

4. Долгих Г.Б. Состояние мозгового кровотока у детей в ранний восстановительный период перинатальных энцефалопатий / Г.Б. Долгих // Российский вестник перинатологии и педиатрии - 2008. - №1. - С.28-30

5. Землянская Н.В. Некоторые особенности перинатальных поражений центральной нервной системы у недоношенных новорожденных: Автореф. дис. ... канд. мед. наук / Н.В. Землянская // - Ростов н/Д, 2006.-17с. patients with first and second degree of prematurity do not have significant hemodynamic disruptions, whereas disruptions in regulation of vascular tonus are observed both in arterial and venous systems in patients with third and fourth degree of prematurity.

2. Bilateral spasm of vertebral arteries is observed in patients with fourth degree of prematurity, which may be due to birth injury, deteriorating severity of motor disorders in current group of patients.

6. Молочникова Е.А. Ультразвуковое дуплексное исследование сосудов головного мозга у недоношенных новорожденных детей с внутриутробными инфекциями / Е.А. Молочникова, В.Г. Белов, К.В. Ватолин, А.И. Кусельман // Ультразвуковая и функциональная диагностика.-2003. - № 4.- 143c.

7. Мубаракшина А.P. Сосудистые нарушения у детей, страдающих синдромом дефицита внимания с гиперактивностью / А.Р. Мубаракшина, М.Г. Тухбатулин, В.Ф. Прусаков // Неврологический вестник им. В.М. Бехтерева. - 2006. - Том XXXVIII. - вып.1-2. - С.26-30 8. Улезко Е.А. Результаты ультразвукового исследования головного мозга у недоношенных новорожденных / Е.А. Улезко // Здравоохранение.-2006. - № 2.-С.32-35. 9. Chung M.Y. Risk factors for hemodynamically-unrelated cystic periventricular leukomalacia in very low birth weight premature kids / M.Y. Chung, P.C. Fang, C.H. Chung // J. Formos. Med. Assoc.-2005.- № 8.-P.571-577 10. Rvachew S. Vocal development of kids with very low birth weight / S. Rvachew, D. Creighton, N. Feldman // Clin. Linguist Phon.-2005.- № 4.- P.275-294 


\title{
XÜLASə \\ VAXTINDAN ӘVVӘL DOĞULAN UŞAQLARDA İNKISŞAFIN REZİDUAL DÖVRÜNDə HEMODINAMIKK POZĞUNLUQLARIN FUNKSIONAL XARAKTERISTIKASI
}

\author{
L.E.Vıqovskaya, A.R.Qaynutdinov \\ Kazan Dövlat Tibb Akademiyası, Kazan, RF
}

Doppleroqrafik tədqiqatın nəticələri müxtəlif kateqoriyalı vaxtından əvvəl doğulmuş körpələrdə serebrovaskulyar pozğunluqların dərəcələrini ayırmağa imkan verir. Daha çox əhəmiyyətə malik hemodinamik pozğunluqlar vaxtından daha çox əvvəl doğulmuş körpələrdə və doğulan zaman onların vəziyyətlərinin ağırlığından asılı olmayaraq xarakterdir. Bu özünü baş və boyun nahiyyəsinin magistral damarlarında qan axınının azalması, həm də hər şeydən əvvəl beyinin venoz sistemində qabarıq dəyişikliklərlə göstərir. Bu xəstə kateqoriyasında baş beynin hemodinamik pozulmalarının yaranması üçün doğuş travması əsas faktor rolunu oynayır. Açar sözlər: vaxtından əvvəl doğulma, hestasiya yaşı, doğulan vaxt vəziyyətin ağırlığı, hemodinamik pozğunluqlar.

\section{РЕЗЮМЕ}

\section{ФУНКЦИОНАЛЬНАЯ ХАРАКТЕРИСТИКА ГЕМОДИНАМИЧЕСКИХ НАРУШЕНИЙ У НЕДОНОШЕННЫХ В РЕЗИДУАЛЬНОМ ПЕРИОДЕ РАЗВИТИЯ}

\author{
Л.Е.Выговская, А.Р.Гайнутдинов \\ Казанская государственная медииинская академия, Казань, РФ
}

Данные допплерографического исследования позволили разграничить степень тяжести цереброваскулярных расстройств у разных категорий недоношенных детей. Наиболее значимые гемодинамические изменения характерны для глубоконедоношенных детей независимо от тяжести состояния при рождении, что проявляется как снижением кровотока по магистральным сосудам головы и шеи, так и прежде всего, выраженными нарушениями в венозной системе мозга. Родовой травматизм является пусковым фактором в реализации гемодинамических нарушений головного мозга у данной категории больных.

Ключевые слова: недоношенность, срок гестации, тяжесть состояния при рождении, гемодинамические нарушения.

Redaksiyaya daxil olub: 18.03 .2014

Çapa tövsiyə olunub: 08.04.2014

Rayçi: t.ü.f.d., X.I.Hasanov 